\title{
Linfoma de Burkitt axilar
}

\author{
Axilar Burkitt lymphoma
}

\section{CASO CLÍNICO}

Varón de 50 años con diagnóstico de infección por VIH, conocida desde junio de 2018, en estadio A3. Actualmente en tratamiento con dolutegravir/abacavir/ lamivudina con carga viral indetectable y niveles de CD4 superiores a 1.000/ $\mathrm{mm}^{3}$. Acude por cuadro de 1 semana de evolución de bultoma axilar derecho doIoroso, adherido a planos profundos, de consistencia dura y crecimiento rápido; no presenta fiebre ni cuadro constitucional acompañante.

Se realizaron pruebas de imagen y analíticas, así como biopsia de la lesión para estudio anatomopatológico, siendo diagnosticado de linfoma difuso $B$ de rasgos morfológicos e inmunohistoquímicos compatibles con Linfoma de Burkitt.

El linfoma de Burkitt es el tumor humano de crecimiento más rápido. Se trata de un linfoma no Hodgkin de células $B$, debido a la translocación cromosómica $(8 ; 14)$ y disregulación del gen MYC, lo que lleva a un alto índice de proliferación.

Se describen tres variantes (africana o endémica, esporádica y asociada a inmunodepresión). En pacientes VIH es un criterio de estadio SIDA.

El diagnóstico se establece mediante la anatomía patológica en la que aparece la imagen típica de "cielo estrellado". El estadiaje mediante PET - TC y el estudio de médula ósea y LCR debe realizarse rápidamente dada la rapidez de replicación de las células tumorales.

Palabras clave: Linfoma de Burkitt, VIH, adenopatías. Keywords: Burkitt lymphoma, HIV, adenopathy.
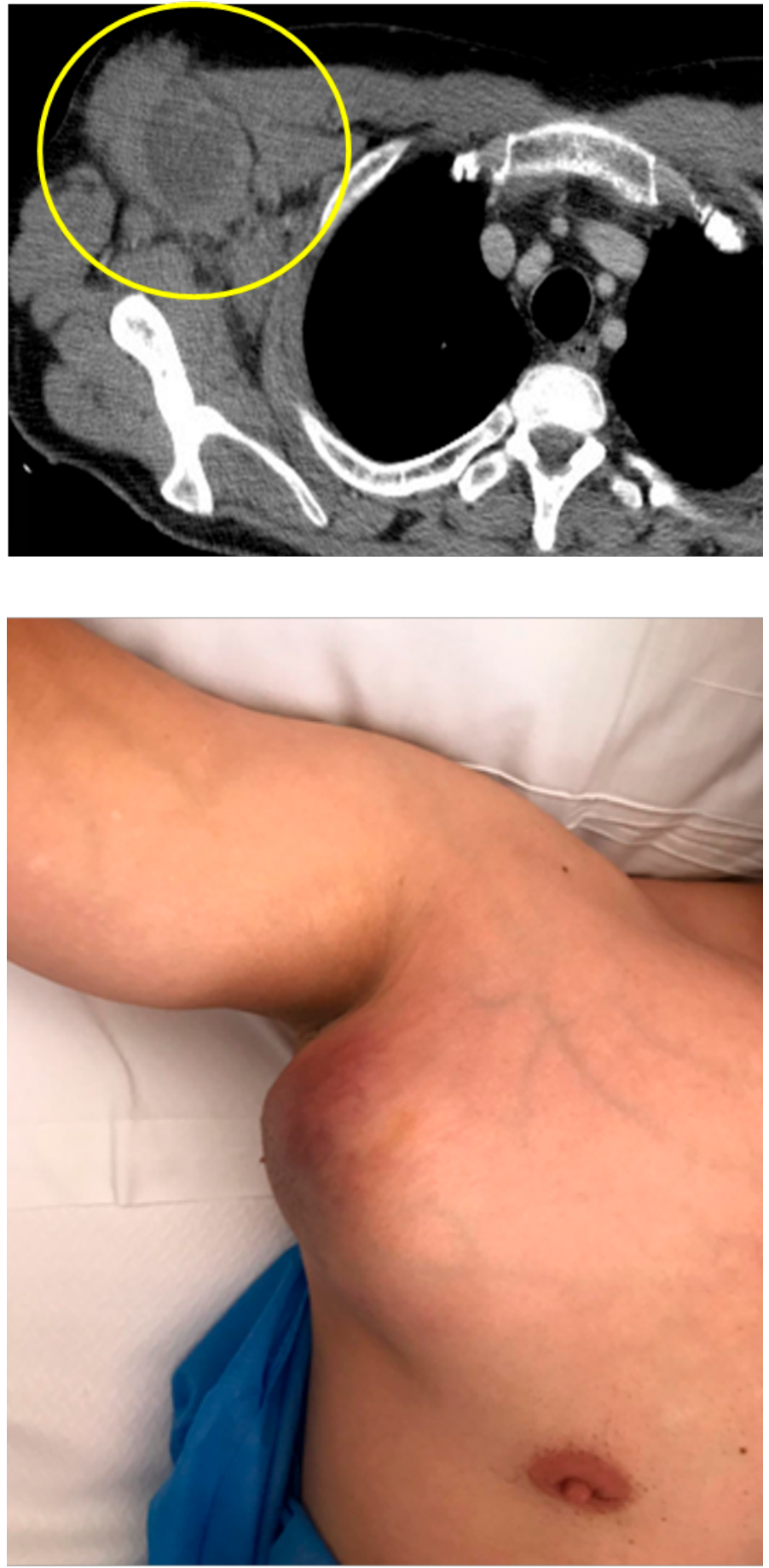

Sonia María Morón Losada, Lucía González González

Servicio de Medicina Interna, Hospital POVISA

Correspondencia: smmoron@povisa.es

Cómo citar este artículo: Morón Losada SM, González González L

Linfoma de Burkitt axilar. Galicia Clin 2021; 82-1: 65

Recibido: 21/11/2019; Aceptado: 21/1/2020 // https://doi.org/10.22546/60/2162 